Prepared in cooperation with

Nevada Department of Conservation and Natural Resources,

Division of Water Resources

Changes in Ground-Water Levels in the Carlin Trend Area, North-Central Nevada, 1989-2003

Scientific Investigations Report 2005-5075

U.S. Department of the Interior

U.S. Geological Survey 
(Back of Cover) 


\section{Changes in Ground-Water Levels in the Carlin Trend Area, North-Central Nevada, 1989-2003}

By Russell W. Plume

Prepared in cooperation with the

NEVADA DEPARTMENT OF CONSERVATION AND NATURAL RESOURCES,

DIVISION OF WATER RESOURCES

Scientific Investigations Report 2005-5075

U.S. Department of the Interior

U.S. Geological Survey 


\section{U.S. Department of the Interior \\ Gale A. Norton, Secretary \\ U.S. Geological Survey \\ P. Patrick Leahy, Acting Director}

U.S. Geological Survey, Carson City, Nevada: 2005

For sale by U.S. Geological Survey, Information Services
Box 25286, Denver Federal Center
Denver, CO 80225
For more information about the USGS and its products:
Telephone: 1-888-ASK-USGS
World Wide Web: http://www.usgs.gov/

Any use of trade, product, or firm names in this publication is for descriptive purposes only and does not imply endorsement by the U.S. Government.

Although this report is in the public domain, permission must be secured from the individual copyright owners to reproduce any copyrighted materials contained within this report.

For additional information contact:

Director

USGS, Nevada Water Science Center

333 W. Nye Lane, Room 203

Carson City, NV 89706-0866

email: GS-W-NVpublic-info@usgs.gov

http://nevada.usgs.gov 


\section{Contents}

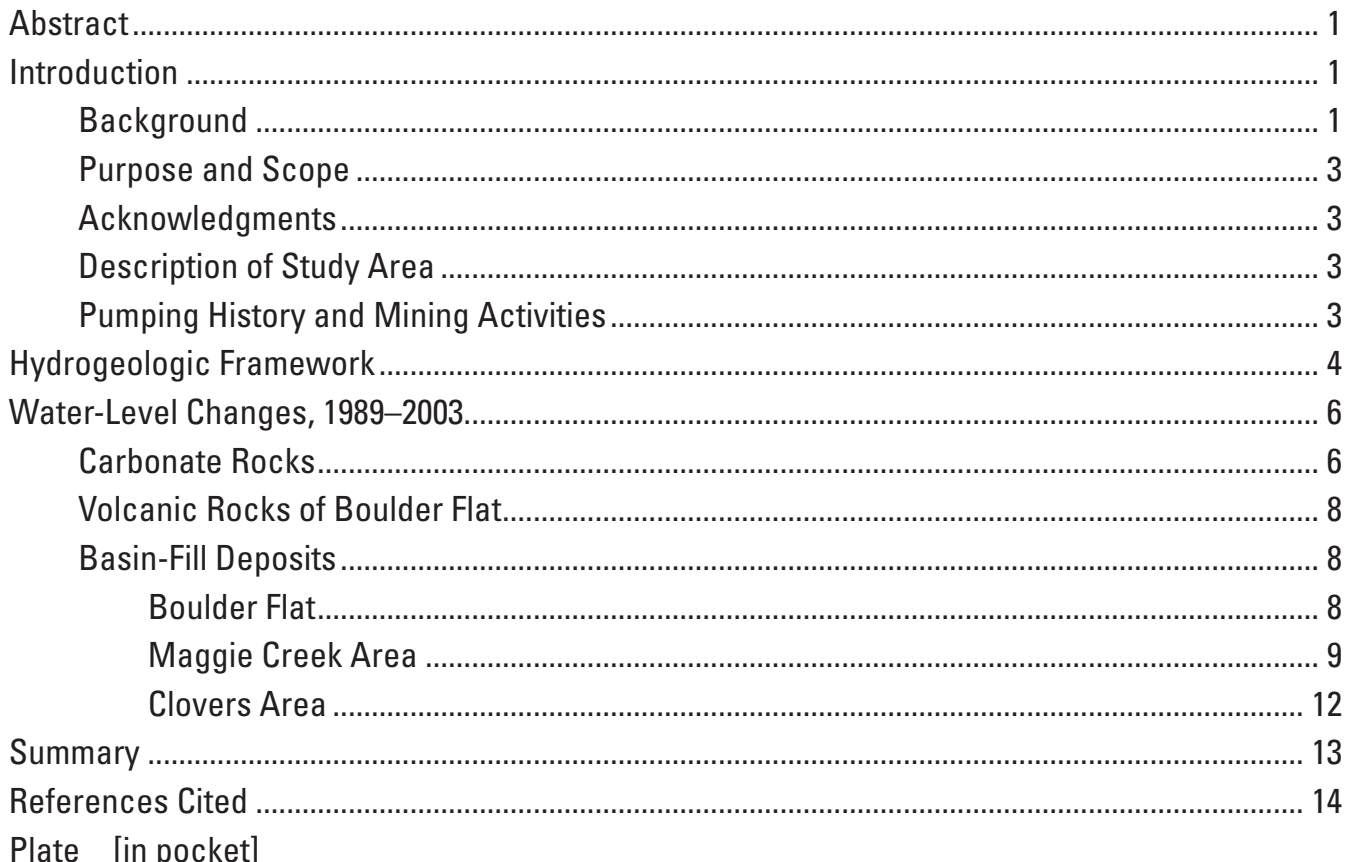

\section{Figures}

Figure 1. Map showing location of hydrographic areas and open-pit gold mines in the Carlin Trend area, north-central Nevada.

Figure 2. Graph showing combined annual ground-water pumpage from mines in the Carlin Trend area, 1989-2003. Total pumped was 1,125,000 acre-feet. Data source is Nevada Division of Water Resources.

Figure 3. Graph showing distribution of water use at the Gold Quarry and Betze Mines in 1998. Total pumpage was 125,000 acre-feet. Data source is Nevada Division of Water Resources

Figure 4. Graphs showing annual ground-water pumpage and concurrent depths to water at selected wells in carbonate rocks, near (A) Gold Quarry Mine, 1991-2003 and (B) Betze Mine, 1993-2003.

Figure 5. Graph showing depth to water in volcanic rocks of Boulder Flat, 1989-2003................... 8

Figure 6. Graph showing depth to water in basin-fill deposits of Boulder Flat, 1989-2003............. 9

Figure 7. Map showing water-level rises in basin-fill deposits near the Gold Quarry Mine, 1993-2003.

Figure 8. Graphs showing depth to water in basin-fill deposits $(A)$ near Gold Quarry Mine and Maggie Creek Reservoir, 1992-2003, and (B) along Maggie Creek, 1993-2003........ 11

Figure 9. Graph showing depth to water at well 20DDDD in Clovers Area, 1993-2003. 12 


\section{Conversion Factors and Vertical Datum}

\begin{tabular}{lcl}
\hline Multiply & By & To obtain \\
\hline & Length & \\
foot (ft) & 0.3048 & meter $(\mathrm{m})$ \\
mile (mi) & 1.609 & kilometer $(\mathrm{km})$ \\
\hline \multicolumn{2}{c}{ Area } & \\
\hline acre & 4,047 & square meter $\left(\mathrm{m}^{2}\right)$ \\
acre-foot $($ acre-ft) & 1,233 & cubic meter $\left(\mathrm{m}^{3}\right)$ \\
square mile $\left(\mathrm{mi}^{2}\right)$ & 2.590 & square kilometer $\left(\mathrm{km}^{2}\right)$ \\
\hline & Flow rate & \\
acre-foot per year (acre-ft/yr) & 1,233 & cubic meter per year $\left(\mathrm{m}^{3} / \mathrm{yr}\right)$ \\
foot per year (ft/yr) & 0.3048 & meter per year $(\mathrm{m} / \mathrm{yr})$ \\
\hline
\end{tabular}

Temperature in degrees Celsius $\left({ }^{\circ} \mathrm{C}\right)$ may be converted to degrees Fahrenheit $\left({ }^{\circ} \mathrm{F}\right)$ as follows:

$$
{ }^{\circ} \mathrm{F}=\left(1.8 x^{\circ} \mathrm{C}\right)+32
$$

Sea level: In this report, "sea level" refers to the National Geodetic Vertical Datum of 1929 (NGVD of 1929, formerly called "Sea-Level Datum of 1929"), which is derived from a general adjustment of the first-order leveling networks of the United States and Canada. 


\title{
Changes in Ground-Water Levels in the Carlin Trend Area, North-Central Nevada, 1989-2003
}

\author{
By Russell W. Plume
}

\section{Abstract}

Ground-water pumpage in support of gold mining activities, including mine dewatering, has resulted in water-level declines and rises in different parts of the Carlin Trend area in north-central Nevada. Total annual pumpage at the Gold Quarry, Carlin, Genesis, and Betze Mines has ranged from about 5,000 acre-feet in 1989 to almost 130,000 acre-feet in 1994 and 1998. Excess water from the mines is stored in the TS Ranch and Maggie Creek Reservoirs.

Aquifers in the Carlin Trend area are comprised of carbonate rocks of Cambrian to Permian age and basin-fill deposits and interbedded volcanic rocks of Tertiary and Quaternary age. Since 1992, water levels in carbonate-rock aquifers near the Gold Quarry Mine have declined as much as 680 feet below an elongate area 12 miles long and 6 miles wide northwest and southeast from the mine. Since 1990, water levels have declined by more than 1,600 feet in the deepest part of the cone of depression at the Betze Mine. The area encompassed by the main part of the cone, which is 7 miles long by 4 miles wide, did not change much during 1993-2003, although its depth had doubled. Near both mines, the cones of depression are bounded by faults acting as barriers to ground-water flow.

Water levels in the volcanic rocks of northern Boulder Flat began to rise soon after the TS Ranch Reservoir began filling in 1990 because of infiltration. Since 1990, the net water-level rise around the reservoir has been 50 feet or more over an area of about 2 square miles, and 20 feet or more over an area of about 60 square miles.

Since 1992, water levels in basin-fill deposits in Boulder Flat have risen 5 feet or more over an estimated area of 20 square miles as a result of (1) use of water from the Betze Mine as a substitute for irrigation pumpage, (2) water from the TS Ranch Reservoir infiltrating volcanic rocks and then flowing southward into adjacent basin-fill deposits, (3) secondary recharge of water from the mine for irrigating about 10,000 acres, and (4) discharge from three new springs in northeastern Boulder Flat.

Water-level declines in carbonate rocks near the Gold Quarry Mine have not affected water levels in overlying basin-fill deposits. Declines were no more than a few feet north and west of the mine because older basin-fill deposits at the base of the Carlin Formation consist of fine-grained poorly permeable sediments. Water levels rose 5 feet to more than 20 feet over an area of 6-7 square miles around the Maggie Creek Reservoir in response to infiltration. A few miles farther south, water levels rose as much as 5 feet over an area of 3 square miles as a combined result of the infiltration of irrigation water and flow of Maggie Creek into permeable volcanic rocks in the stream channel.

An area of 1,900 acres about 10 miles north of Battle Mountain in the Clovers Area has been pumped for irrigation since the early 1970's. Since 1989, water levels have declined 5-15 feet over an area of 15 square miles.

\section{Introduction}

\section{Background}

The Carlin Trend is a northwest trending alignment of large, low-grade gold deposits in north-central Nevada. Most of the gold deposits along the trend are north of the Humboldt River in or near six topographic basins, also referred to as hydrographic areas ${ }^{1}$, which together constitute the Carlin Trend area (fig. 1). The six areas are the Susie Creek Area (hydrographic area number 50), Maggie Creek Area (51), and Marys Creek Area (52), east of the Tuscarora Mountains; Boulder Flat (61), Rock Creek Valley (62) and Willow Creek Valley (63), west of the mountains.

The first large-scale gold mining along the Carlin Trend began in the early 1960's. By 1988, mining was underway at several large gold deposits. At this time concerns developed over the potential effects of mining pumpage on the groundwater and surface-water resources of areas near the mines. This concern increased when pumping rates began to increase in 1990 as a result of the need to dewater some of the mines.

\footnotetext{
${ }^{1}$ Formal hydrographic areas in Nevada were delineated systematically by the USGS and Nevada Division of Water Resources in the late 1960's for scientific and administrative purposes (Cardinalli and others, 1968, and Rush, 1968). The official hydrographic-area names, numbers, and geographic boundaries continue to be used in USGS scientific reports and Division of Water Resources administrative activities.
} 


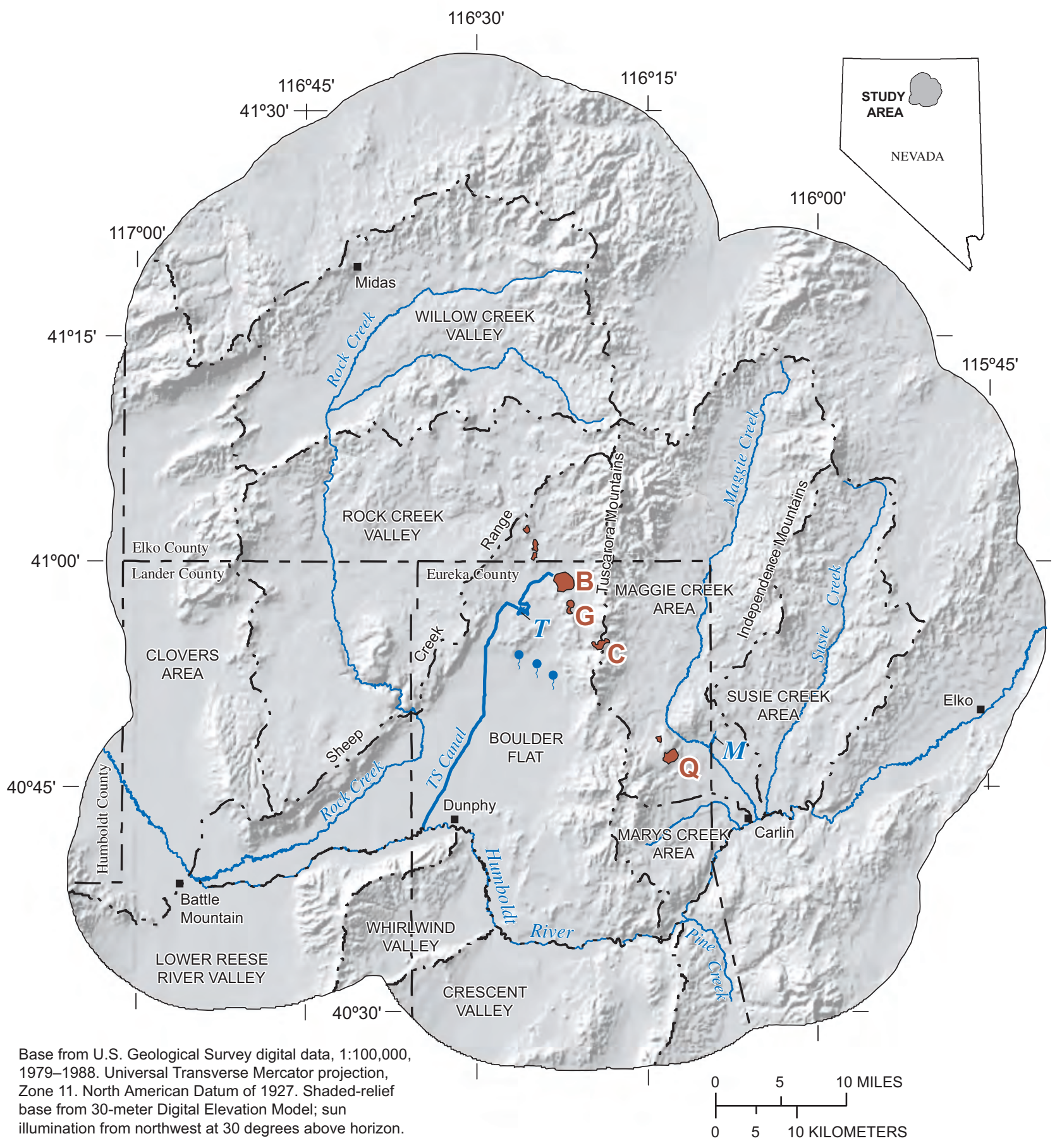

EXPLANATION

Open-pit gold mine-Letters indicate Betze (B), Carlin (C), Genesis (G), and Gold Quarry (Q) Mines

Reservoir-Used to store excess water from mine. Letters indicate Maggie Creek (M) and TS Ranch (T) Reservoirs

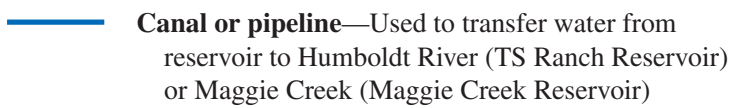
or Maggie Creek (Maggie Creek Reservoir)

- - Hydrographic-area boundary

Spring in northern Boulder Flat—Did not exist prior to infiltration at TS Ranch Reservoir

Figure 1. Location of hydrographic areas and open-pit gold mines in the Carlin Trend area, north-central Nevada. 
In 1988, the U.S. Geological Survey (USGS) began an investigation of the water resources of the Maggie, Marys, and Susie Creek Areas (Plume, 1995) in response to the concerns over pumpage for mining purposes. The objective of this study was to evaluate the water resources of the area near the Gold Quarry Mine and the potential effects of mine related pumping. In addition, the USGS began a study to evaluate the water resources of the Carlin Trend area and the effects of pumping. This study was completed in 1993 (Maurer and others, 1996).

In addition to these two studies, hydrologic conditions in the Carlin Trend area have been monitored since 1990 by the mining companies and USGS. The mining companies regularly report the results of their water-level monitoring and analyses of hydrologic conditions near the Betze and Gold Quarry Mines, which are the two largest mines in the area (fig 1). However, no systematic attempt has been made since 1993 to re-evaluate changes in ground-water levels across the original Carlin Trend study area. This report presents the results of a study of water-level changes in the Carlin Trend area during 1989-2003.

\section{Purpose and Scope}

The purposes of this report are twofold. The first is to document ground-water levels in the Carlin Trend area during spring 2003. The second is to evaluate water-level changes that have occurred in the area since mining-related pumping began in 1989. Thus, the scope of this report is narrower than the previous Carlin Trend study (Maurer and others, 1996), which included streamflow conditions, water budgets, and water quality in addition to ground-water levels.

\section{Acknowledgments}

The study documented in this report was done in cooperation with the Nevada Department of Conservation and Natural Resources, Division of Water Resources. Johnny Zhan of Barrick Management Corporation and Paul Pettit of Newmont Mining Corporation provided much of the data used for evaluating water-level changes in the Carlin Trend area. Both have also provided the author assistance and advice during analysis of the data. Matt Dillon of the Nevada Division of Water Resources provided water-level data for the Clovers Area (64) on the west side of the study area. Finally, ranchers and land owners provided the USGS access to their lands and wells. Their cooperation and assistance is appreciated.

\section{Description of Study Area}

The main part of the Carlin Trend study area consists of six hydrographic areas on the east and west sides of the Tuscarora Mountains. The Susie Creek, Maggie Creek, and Marys Creek Areas are on the east side, and Boulder Flat, Rock Creek, and Willow Creek Valleys are on the west side (fig. 1). The Humboldt River forms the southern boundary for these six areas. The three areas on the east side of the
Tuscarora Mountains are drained by Susie, Maggie, and Marys Creeks. The areas on the west side are drained by Rock Creek and its tributaries. The study area also includes northern and eastern parts of Crescent Valley (54), Whirlwind Valley (60), and Lower Reese River Valley (59), and the eastern part of the Clovers Area (64). The reason for including parts of these four additional areas is to better assess ground-water conditions along the Humboldt River and in an irrigated area about $10 \mathrm{mi}$ north of Battle Mountain. Locations of each area are shown in figure 1.

\section{Pumping History and Mining Activities}

Historic ground-water pumpage in the Carlin Trend area has been for municipal, domestic, stock-watering, irrigation ${ }^{2}$, and mining purposes. Pumpage from municipal wells at Carlin, Dunphy, and Midas probably has been less than 100 acre-ft/yr during the past 10-20 years. Pumpage for domestic and stock-watering purposes has not been quantified, but is believed to be minimal.

Ground water has been pumped for irrigation purposes in the Maggie Creek Area, Clovers Area, and Boulder Flat. Annual pumpage for irrigation of about 100 acres of alfalfa in the Maggie Creek Area was about 300 acre-ft until 1993. Since then, irrigation needs have been met with water from the Gold Quarry Mine. About 1,900 acres of alfalfa are irrigated in the Clovers Area at annual rates of about 6,000 acre-ft.

Prior to 1992, ground-water pumpage in Boulder Flat irrigated about 4,100 acres of alfalfa. Total annual pumpage was about 12,000 acre-ft. In 1990-91, irrigation needs in Boulder Flat began to be provided by water from the Betze Mine and irrigation pumpage ceased. The irrigated area was expanded to about 10,000 acres, and about 28,000 acre-ft of water from mine dewatering was used to irrigate the fields in 1998 (Plume, 2003, p. 15).

Ground-water pumping for mining purposes has been underway in the Carlin Trend area for the past 40 years. Prior to the late 1980's, however, annual pumpage rates probably were no more than a few thousand acre-feet, and water was pumped only for consumptive uses, which include mining, milling, and dust control. Annual pumpage ${ }^{3}$ increased dramatically in the early 1990's (fig. 2) as open-pit mines deepened and water was pumped for dewatering purposes ${ }^{4}$. Combined annual pumpage at the Gold Quarry, Betze, Carlin, and Genesis Mines increased from about 5,000 acre- $\mathrm{ft}$ in 1989 to 129,000 acre-ft in 1994 and 128,000 acre-ft in 1998 (fig. 2).

\footnotetext{
${ }^{2}$ Pumpage volumes based on application rate of 3 feet per year (Plume, 2003, p. 11).

${ }^{3}$ Nevada Division of Water Resources files are the source of all pumping data for mining purposes.

${ }^{4}$ Ground water pumped for mine dewatering purposes is herein referred to as excess water. In the winter, this water is stored at the TS Ranch and Maggie Creek Reservoirs, and in the summer, it is used for irrigation or is released to Maggie Creek near the Gold Quarry Mine. Excess water from the Betze Mine was released to the Humboldt River by way of the TS Canal (fig. 1 and pl. 1) over a period of 18 months from late 1997 to early 1999.
} 


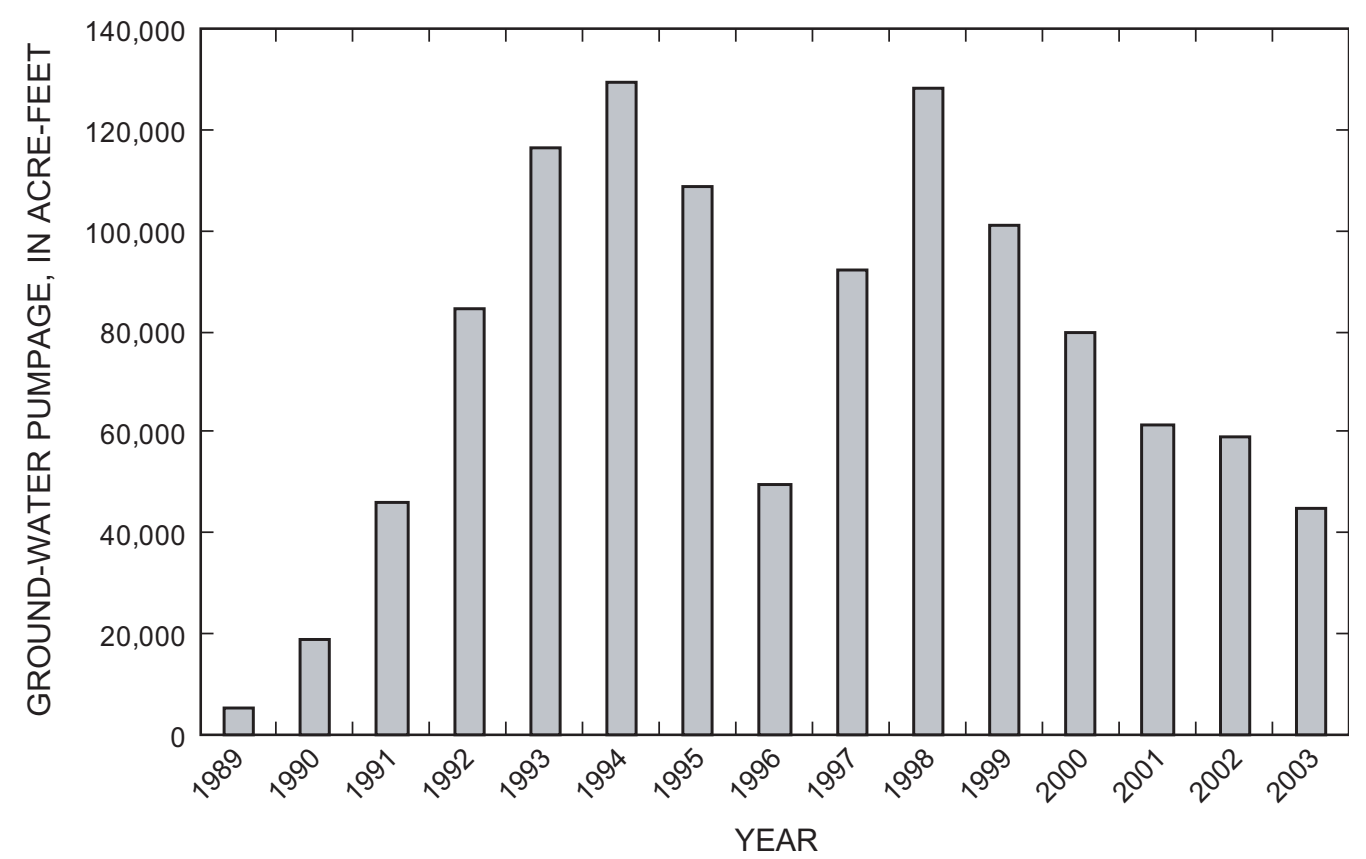

Figure 2. Combined annual ground-water pumpage from mines in the Carlin Trend area, 1989-2003. Total pumped was 1,125,000 acre-feet. Data source is Nevada Division of Water Resources.

Excess water from the Gold Quarry and Betze Mines is stored in the Maggie Creek and TS Ranch Reservoirs, respectively (fig. 1; pl. 1). Soon after filling of the TS Ranch Reservoir began in 1990, water began infiltrating fractured volcanic rocks beneath the reservoir floor. A few months later the water began emerging as three springs in northern Boulder Flat ${ }^{5}$ (fig. 1 and pl. 1), and areas south of the springs became saturated to land surface. As a result, pumping rates were decreased at the Betze Mine from about 100,000 acre- $\mathrm{ft}$ in 1993-94 to 24,000 acre-ft in 1996 (fig. 4B) while more efficient ways to manage the excess water were developed. By 1998, pumpage had increased to about 100,000 acre-ft, but in 2001-2003, the pumpage decreased to an annual rate of about 45,000 acre-ft (fig. 4B).

Total ground water pumped for mining purposes during 1989-2003 was about 1,125,000 acre-ft (fig. 2). The distribution of total pumpage during 1998 (fig. 3) provides an example of how excess water from the Gold Quarry and Betze Mines has been managed. Of the total pumpage in 1998, 8 percent was for consumptive use at the two mines, 11 percent was returned to local aquifers by infiltration, 24 percent was used for irrigation, 52 percent was released to the Humboldt River or Maggie Creek, and 5 percent was lost to evaporation from the two reservoirs (fig. 3).

\footnotetext{
${ }^{5}$ The springs had not existed previous to mine dewatering and reservoir infiltration.
}

\section{Hydrogeologic Framework}

Each of the six hydrogeologic units defined in the Carlin Trend area (pl. 1) is comprised of one or more mapped geologic units (Stewart and Carlson, 1976). Four hydrogeologic units function as aquifers, whereas two other units generally impede the movement of ground water. Hydrogeologic units that comprise aquifers are, from oldest to youngest: (1) carbonate rocks of Cambrian to Permian age, (2) volcanic rocks of Tertiary and Quaternary age, (3) older basin-fill deposits of Tertiary age, and (4) younger basin-fill deposits of Tertiary and Quaternary age. For purposes of evaluating water-level changes over most of the study area, the latter three units are grouped together because volcanic rocks and basin-fill deposits commonly are interbedded and the three units are thought to be hydraulically connected (Plume, 1995, p. 61, and Maurer and others, 1996, p. 33, 34, and 39). Volcanic rocks of northern Boulder Flat are an exception because water levels in these rocks have fluctuated separately from water levels in nearby basin-fill deposits. Two other hydrogeologic units are siltstones of Ordovician to Devonian age and granitic rocks of Jurassic and Tertiary age. Both of these units generally impede ground-water flow.

Carbonate rocks are exposed to differing extents in mountain ranges in the eastern parts of the Carlin Trend area (pl. 1). These rocks consist of limestone and dolomite, including lesser amounts of clastic sedimentary rocks, of Cambrian, Ordovician, and Devonian age (Stewart and Carlson, 1976), and are exposed to a limited extent in the southern Tuscarora Mountains and in some areas of the Independence Range by 


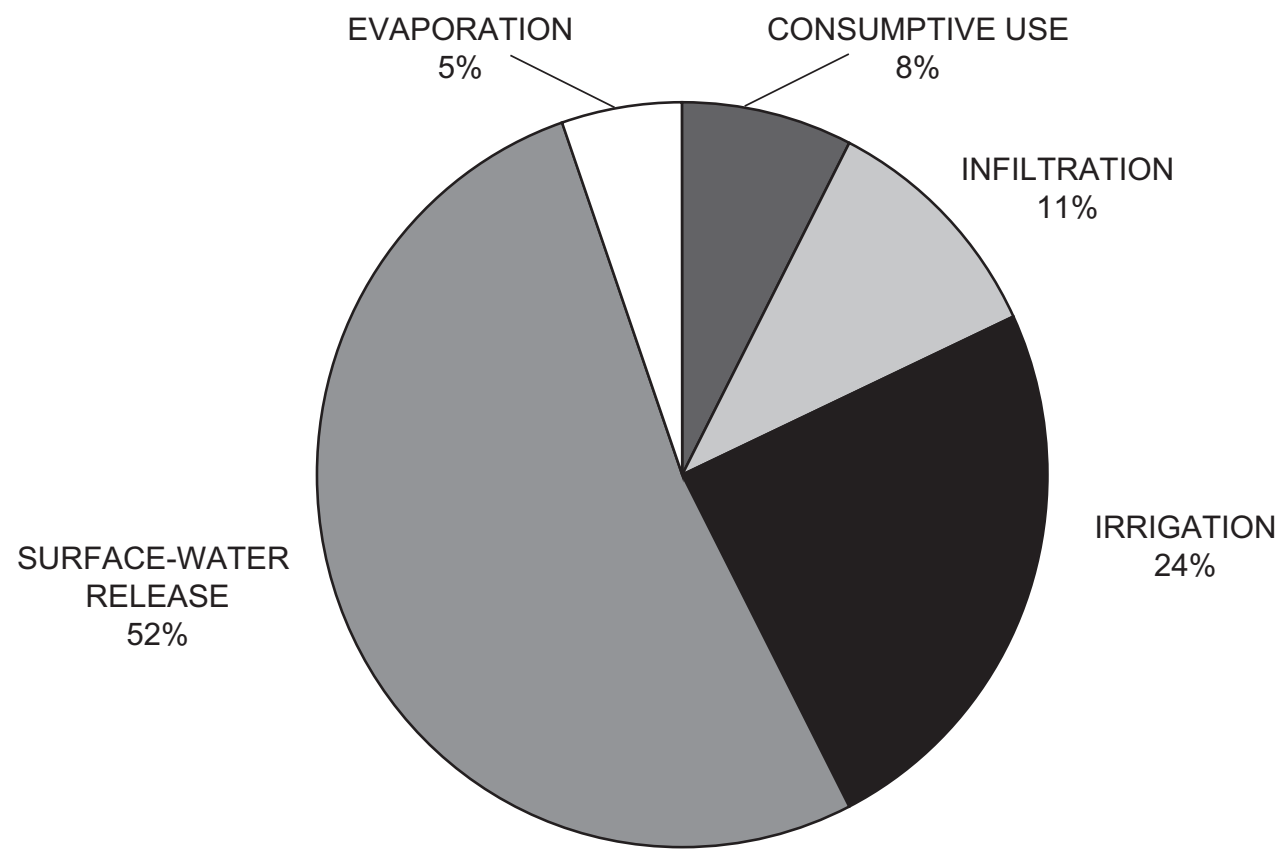

Figure 3. Distribution of water use at the Gold Quarry and Betze Mines in 1998. Total pumpage was 125,000 acre-feet. Data source is Nevada Division of Water Resources.

faulting and erosion of the overlying siltstones. Carbonate rocks of Devonian to Permian age are exposed extensively farther east in the Adobe Range (pl. 1). However, these carbonate rocks include substantial quantities of clastic sedimentary rocks (Stewart and Carlson, 1976). Carbonate rocks underlie siltstones and volcanic rocks at uncertain depths in western parts of the study area. Carbonate rocks are relatively permeable, especially those in the Tuscarora Mountains and Independence Mountains, because of extensive fracturing and subsequent solution widening of fractures.

Siltstones are exposed extensively in the Tuscarora and Independence Mountains and to a lesser extent in the northern and western parts of the study area (pl. 1). These rocks consist of a variety of clastic sedimentary rocks and chert of Ordovician, Silurian, and Devonian age (Stewart and Carlson, 1976). Although siltstones are extensively fractured, they are not as permeable as carbonate rocks because they are not nearly as susceptible to solution widening. The differing permeability of these two units is illustrated by water levels near the Betze Mine in the Tuscarora Mountains. Water levels in siltstones are perched above water levels in the underlying carbonate rocks (Paul Pettit, Newmont Mining Corp., oral commun., 2004). The low permeability of the siltstones also is indicated by the presence of perennial streams in the northern Tuscarora Mountains where siltstones are by far the predominant rock type (pl. 1). Perennial streams are rare in the southern Tuscarora Mountains and in the Independence Mountains where exposures of carbonate rocks are more common.

Granitic rocks of Jurassic and Tertiary age are exposed in the northern and central Independence Mountains and at scattered locations in the Tuscarora Mountains, including the south side of the Betze Mine. Granitic rocks generally impede the movement of ground water because the rocks are poorly permeable, extend to substantial depths, and can be much more areally extensive at depth than the outcrops. Granitic rocks on the south side of the Betze Mine have been informally named the Goldstrike intrusive, and function as a barrier to ground-water flow (Maurer and others, 1996, p. 62).

Volcanic rocks in the study area consist of flows of basalt and andesite, domes, shallow intrusive bodies of rhyolite, and silicic tuffs. Volcanic rocks are exposed extensively in mountain ranges west of the Tuscarora Mountains, and to a lesser extent to the east (pl. 1). These rocks also underlie and are interbedded with older basin-fill deposits. Ground water occurs in fractures and interflow zones in volcanic rocks.

Volcanic rocks are penetrated by pairs of shallow and deep wells at three sites between northern Boulder Flat and eastern Rock Creek Valley (NA-28, NA-49, and NA-53 on pl. 1). At each of the sites, the deep well penetrates relatively permeable volcanic rocks that are in hydraulic contact with underlying permeable carbonate rocks (Johnny Zhan, Barrick Management Corp., written commun., 2004). Volcanic rocks penetrated by the shallow well at each site are relatively impermeable, and water levels in these rocks are perched above water levels in the deeper volcanic rocks which are being dewatered along with the underlying carbonate rocks (Johnny Zhan, Barrick Management Corp., written commun., 2004). Water levels in the deep wells are used along with water levels in carbonate-rock wells to analyze water-level declines caused by dewatering of the Betze Mine in the next section of this report. 
Basin-fill deposits comprise the most extensive aquifers in the Carlin Trend area (pl. 1). They range in thickness from 1,000 to 3,000 ft west of the Tuscarora Mountains to as much as 4,000 to $8,000 \mathrm{ft}$ east of the mountains (Plume and Ponce, 1999; and Plume, 1995, p. 29). Older basin-fill deposits consist of semi-consolidated clay, silt, sand, gravel, and boulders that range from well sorted to unsorted depending on the depositional environment. These environments include lacustrine and fluvial. For instance, older basin-fill deposits in the Carlin Trend area consist of fine-grained lake sediments at their base and unsorted fanglomerates near their top (Alan Wallace, U.S. Geological Survey, oral commun., 2003). In addition, older basin-fill deposits commonly contain interbedded volcanic rocks. Younger basin-fill deposits generally consist of unsorted clay, silt, sand, gravel, and boulders on alluvial fans; finergrained and better-sorted sediments in basin lowlands; and well sorted clay, silt, sand, and gravel in stream flood plains.

The effects of faults on ground-water flow in the Carlin Trend area are variable. Some faults function as relatively impermeable flow barriers. Others may function as conduits for ground-water flow, although evidence for this is sparse. The effects of some faults as impermeable boundaries are evident as differences in water levels on each side of the fault. This is the case for the GPX and Post faults, which are west of the Gold Quarry Mine and south of the Betze Mine, respectively (pl. 1). Pre-pumping water levels originally differed by 800 to $1,000 \mathrm{ft}$ across the GPX fault (Paul Pettit, Newmont Mining Corp., oral commun., 2004). Water levels now differ by more than 1,000 ft across the GPX fault and by more than 1,000 ft across the Post fault (pl. 1). The Siphon fault juxtaposes carbonate and volcanic rocks south and west of the Betze Mine, and the fault is partly concealed by younger basin-fill deposits (pl. 1). Prior to mining activities, water levels in the carbonate rocks stood about $500 \mathrm{ft}$ above water levels in the volcanic rocks. At present (2004), water levels in the carbonate rocks stand about 1,100 ft below water levels in the volcanic rocks (Johnny Zhan, Barrick Management Corp., written commun., 2004). These large differences in water levels between the two units further illustrate the lack of a hydraulic connection across the fault. However, the effects of many faults are difficult to predict until pumping stresses are applied to the carbonate rocks.

\section{Water-Level Changes, 1989-2003}

Water levels in the Carlin Trend area are monitored by mining companies, the Nevada Division of Water Resources, and USGS. As of March 2003, water levels near the Betze Mine in northern Boulder Flat were being monitored by Barrick Goldstrike Mines, Inc. at 68 sites and near the Gold Quarry Mine in the Susie Creek, Maggie Creek, and Marys Creek Areas by Newmont Mining Corporation, also at 68 wells. Each site has from one to three wells completed at differing depths in one of the hydrogeologic units described in the preceding section of this report. Water levels near the two mines are continuously or periodically monitored at a total of about 160 wells.

The Nevada Division of Water Resources measures water levels every March in the Clovers Area about $10 \mathrm{mi}$ north of Battle Mountain. The purpose is to monitor water levels in an area where ground water is pumped for irrigation purposes.

Since 1988, the USGS has measured water levels in the Carlin Trend area. The water levels are measured at wells completed in basin-fill deposits and to a lesser extent volcanic rocks, mostly in areas that are beyond the effects of mine dewatering.

Water-level changes described in the following sections are based on water levels measured in: (1) carbonate rocks by the mining companies near the Betze and Gold Quarry Mines, (2) volcanic rocks of northern Boulder Flat by Barrick Goldstrike Mines, Inc., (3) basin-fill deposits of Boulder Flat and the Maggie Creek Area by the mining companies and USGS, and (4) basin-fill deposits of the Clovers Area by the Nevada Division of Water Resources.

\section{Carbonate Rocks}

Water levels in carbonate rocks at the Gold Quarry Mine declined as much as $680 \mathrm{ft}$ at well GQP-15 from 1991 to 2003 as a result of pumpage of ground water for dewatering the mine (fig. 4A). Declines were about $90 \mathrm{ft}$ from 1991 through 1993 when annual pumping rates were 10,000 acre-ft or less. Annual pumping rates increased from 23,000 acre-ft in 1994 to 29,000 acre-ft in 1997 and water levels declined an additional $450 \mathrm{ft}$. Since 1998, annual pumping rates have decreased to about 15,000 acre-ft, and water levels have declined an additional $140 \mathrm{ft}$.

The lines of equal water-level decline for carbonate rocks at Gold Quarry Mine define an elongate area about $12 \mathrm{mi}$ long and as much as 6 mi wide (pl. 1). The area extends from southeast of Gold Quarry Mine to the northwest. The pattern of the lines suggests that both the Tuscarora Mountains fault, and thick, poorly permeable basin-fill deposits adjacent to carbonate rocks east of Maggie Creek, may function as relatively impermeable barriers on the northwest. However, this cannot be confirmed because no carbonate rock monitoring wells have been installed in this part of the study area because of excessive depths to the rocks. The GPX fault functions as a boundary to the southwest and an unmapped fault probably functions as an impermeable boundary to the northeast. The water-level declines in carbonate rocks have been at depths of 1,000 ft or more below land surface (Plume, 1995, p. 28-29).

Water-level declines around the Betze Mine had exceeded $800 \mathrm{ft}$ by 1993 (Maurer and others, 1996, p. 62). The cone of depression was bounded on the northeast and southwest by faults, on the southeast by relatively impermeable granitic rocks of the Goldstrike intrusive, and possibly on the north- 
A
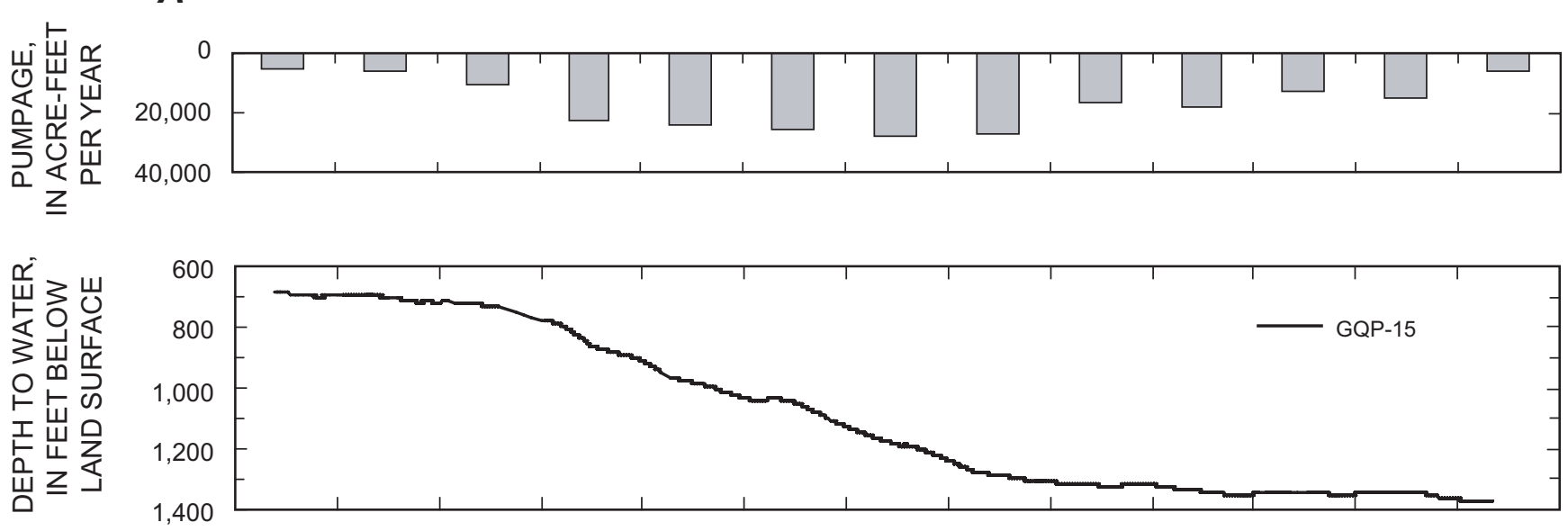

\section{B}
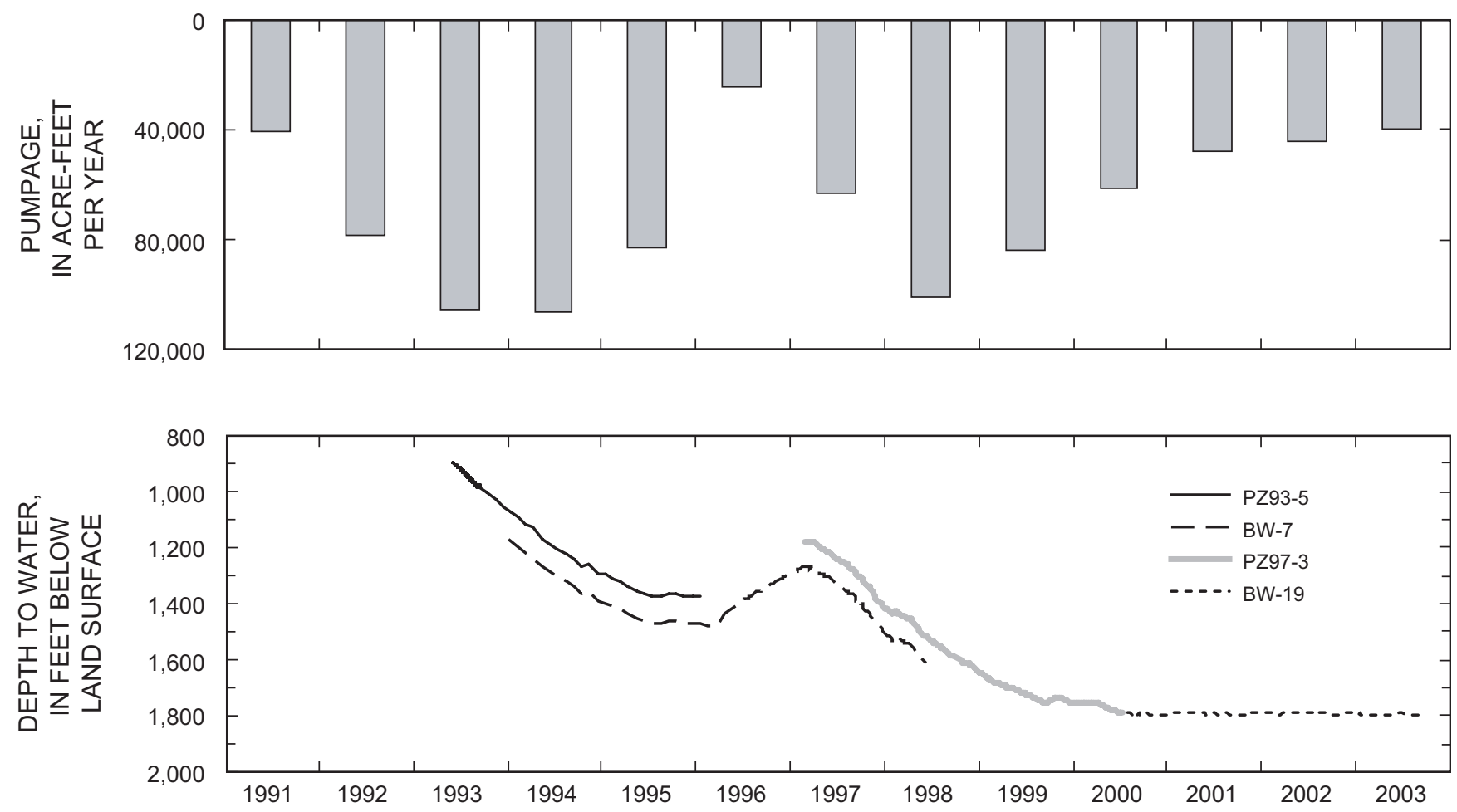

Figure 4. Annual ground-water pumpage and concurrent depths to water at selected wells in carbonate rocks, near ( $A$ ) Gold Quarry Mine, 1991-2003 and (B) Betze Mine, 1993-2003.

west by impermeable siltstones (Maurer and others, 1996, p. 64). Total ground water pumped since 1991 has been about 880,000 acre-ft (fig. 4B). As of 2003, water levels had declined by more than $1,600 \mathrm{ft}$ in the deepest part of the cone of depression (pl. 1). The area encompassed by the main part of the cone of depression, which is about $7 \mathrm{mi}$ long and 4 mi wide, did not change much during 1993-2003; however, its depth had doubled. In addition, the cone of depression extended an additional $5 \mathrm{mi}$ to the southeast as a result of continued dewatering of the Betze Mine (pl. 1). The westward inflections of the -100 and $-200 \mathrm{ft}$ lines of equal water-level decline south of the mine demonstrate the hydrologic effects of poorly permeable granitic rocks of the Goldstrike intrusive (pl. 1). The barrier effect of the Siphon fault also is evident where the same two lines of equal water-level decline are closely spaced adjacent to the east side of the fault. The Post fault appears to bound water-level declines of $800 \mathrm{ft}$ or more to the east, but does not appear to bound declines of $200 \mathrm{ft}$ or less.

Figure $4 B$ shows a more detailed history of water-level decline at the Betze Mine using depths to water from four wells on the northwest side of the open-pit mine. Water levels in this area declined about $470 \mathrm{ft}$ from July 1993 through January 1996 (well PZ93-5, fig. 4B). When pumping rates were reduced to find more efficient ways of dealing with 
excess water from the mine, water levels rose about $200 \mathrm{ft}$ from spring 1996 to spring 1997 (well BW-7, fig. 4B). Once previous pumping rates resumed, water-levels again began to decline, and as of summer 2000 had declined an additional $610 \mathrm{ft}$ since spring 1997 (well PZ97-3, fig. 4B). Since summer 2000, target depths for water levels at the mine have been reached. As a result, water-level declines have ceased because of reduced pumping rates (fig. 4B). The composite decline since June 1993 at the four wells has been about $880 \mathrm{ft}$.

\section{Volcanic Rocks of Boulder Flat}

Water levels in the volcanic rocks of northern Boulder Flat began to rise soon after filling of the TS Ranch Reservoir began in 1990 (Maurer and others, 1996, p. 64-65). These water-level rises occurred because of infiltration into fractured volcanic rocks beneath the reservoir. Since then, the net waterlevel rise around the reservoir has been $50 \mathrm{ft}$ or more over an area of about $2 \mathrm{mi}^{2}$ and $20 \mathrm{ft}$ or more over an area of about $60 \mathrm{mi}^{2}$ (pl. 1). This includes areas of exposed volcanic rocks near the reservoir and in the Sheep Creek Range and in volcanic rocks that underlie basin-fill deposits in northern Boulder Flat. Once pumping for dewatering ceases, water levels in the volcanic rocks probably will decline to pre-dewatering levels because the TS Ranch Reservoir will no longer be used to store water.

The water-level rises in the volcanic rocks shown on plate 1 do not reflect year-to-year changes that resulted from pumping variations since 1990 . Figure 5 shows water levels at two wells completed in volcanic rocks about 4,000 ft west (NA-8) and 16,000 ft southeast (TS-2) of the TS Ranch Reservoir (pl. 1). Water levels in both wells began to rise in late 1990 to early 1991 (fig. 5). Water levels rose about $45 \mathrm{ft}$ at well TS-2 and $90 \mathrm{ft}$ at well NA-8 during the period from early 1991 through April 1996. Water levels then declined about $20 \mathrm{ft}$ and $60 \mathrm{ft}$ at TS-2 and NA-8, respectively, during 1996-97 when pumping rates for dewatering the mine were reduced. Since 1999, annual water levels have fluctuated about $5 \mathrm{ft}$ and $20 \mathrm{ft}$ at wells TS-2 and NA-8, respectively, in response to filling of the TS Ranch Reservoir in the winter and use of water from the mine for irrigation in the spring and summer.

\section{Basin-Fill Deposits}

\section{Boulder Flat}

Water levels in basin-fill deposits in Boulder Flat have risen since 1992 for several reasons. First, water levels began to rise when excess water from the Betze Mine began to be used for irrigation in place of water from irrigation wells. The cessation of irrigation pumping resulted in corresponding water-level rises. Second, water infiltrating volcanic rocks beneath the TS Ranch Reservoir eventually resulted in waterlevel rises in overlying basin-fill deposits in northern Boulder Flat. Third, the application of water from the Betze Mine for irrigation of about 10,000 acres in northern and eastern Boulder Flat has contributed to water-level rises. Finally, water that discharges at the three new springs in northeastern Boulder Flat has resulted in saturation of basin-fill deposits downslope from the springs. As a result, water levels rose 5 to $20 \mathrm{ft}$ over an estimated area of at least $20 \mathrm{mi}^{2}$ in Boulder Flat (pl. 1). The northeastward inflections of lines of equal water-level

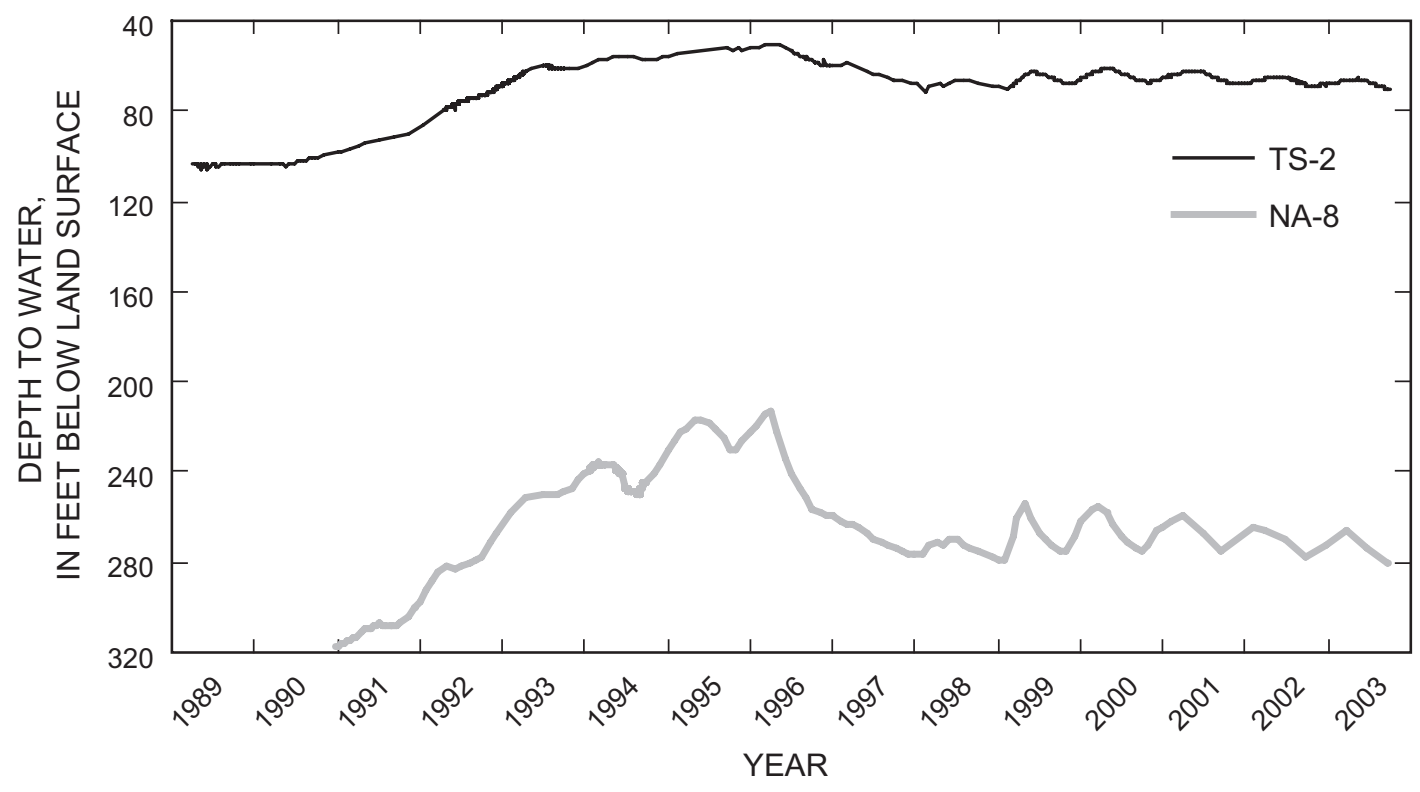

Figure 5. Depth to water in volcanic rocks of Boulder Flat, 1989-2003. 
change coincide with a broad, poorly defined drainage (see Rodeo Creek SW, Nev., 7.5-minute quadrangle). The topography in this part of Boulder Flat directs discharge from the three springs along the drainage, thus resulting in a conspicuous northeast trending ridge where water levels have risen in certain areas to land surface.

Depending on their location in Boulder Flat, water levels at individual wells in basin-fill deposits have risen for one or more of the reasons listed above. Well TS-3 is in northeastern Boulder Flat about 6 mi south of the TS Ranch Reservoir and 3 mi south of well TS-2 (pl. 1). During 1990-92, water levels changed little at well TS-3 (fig. 6) while water levels rose in volcanic rocks at well TS-2 a few miles to the north (fig. 5). Water levels at well TS-3 then abruptly rose about $20 \mathrm{ft}$ in late 1992 and early 1993. Since then, water levels at the well have fluctuated only a few feet each year in response to storage of water in the TS Ranch Reservoir during the winter and irrigation during spring and summer.

Well NA-32 is located about 8 mi southwest of the TS Ranch Reservoir in the middle of 10,000 acres of fields irrigated with excess water from the Betze Mine (pl. 1). Water levels at this well declined during the summer of 1991 probably in response to local irrigation pumping that continued until water from the Betze Mine began to be used for irrigation (fig. 6). From late 1991 through 2000, water levels gradually rose about $30 \mathrm{ft}$ in response to cessation of irrigation pumping and secondary recharge from annual application of as much as 28,000 acre-ft of water from the mine for irrigation (Plume, 2003, p. 15). From 2000 through 2002, water levels at well NA-32 have declined about $5 \mathrm{ft}$ because the quantities of water used for irrigation have been reduced (Johnny Zhan, Barrick Management Corp., written commun., 2004; fig. 6).
Well TS-6, located about $13 \mathrm{mi}$ south of the TS Ranch Reservoir, is near an area of about 3,100 acres where irrigation pumping ceased in 1993 when water from the Betze Mine began to be used for irrigation purposes (pl. 1). Water levels at well TS-6 fluctuated in 1989-92 in response to local irrigation pumpage (fig. 6). Since then, water levels at the well have steadily risen about $20 \mathrm{ft}$ as a result of the cessation of local irrigation pumpage.

\section{Maggie Creek Area}

Water-level declines in carbonate rocks resulting from Gold Quarry Mine dewatering from 1993 to 2003 do not appear to have had much affect on water levels in overlying basin-fill deposits in the Maggie Creek Area (fig. 7). No declines in basin-fill deposits were observed in areas south and east of the mine, and declines generally were no more than a few feet northwest of the mine, because the base of the Carlin Formation (older basin-fill deposits) consists of fine-grained lacustrine (shallow lake) deposits that are poorly permeable. As a result, there is little hydraulic connection between the deep carbonate rocks that are being dewatered and overlying basin-fill deposits. Well MK-2 is used to monitor water levels in the older basin-fill deposits of the Carlin Formation at depths of 180-200 ft. The net water-level change at this well during 1993-2002 was a decline of about $2 \mathrm{ft}$ (fig. 8A). In contrast, water-level declines in underlying carbonate rocks were more than $650 \mathrm{ft}$ (pl. 1).

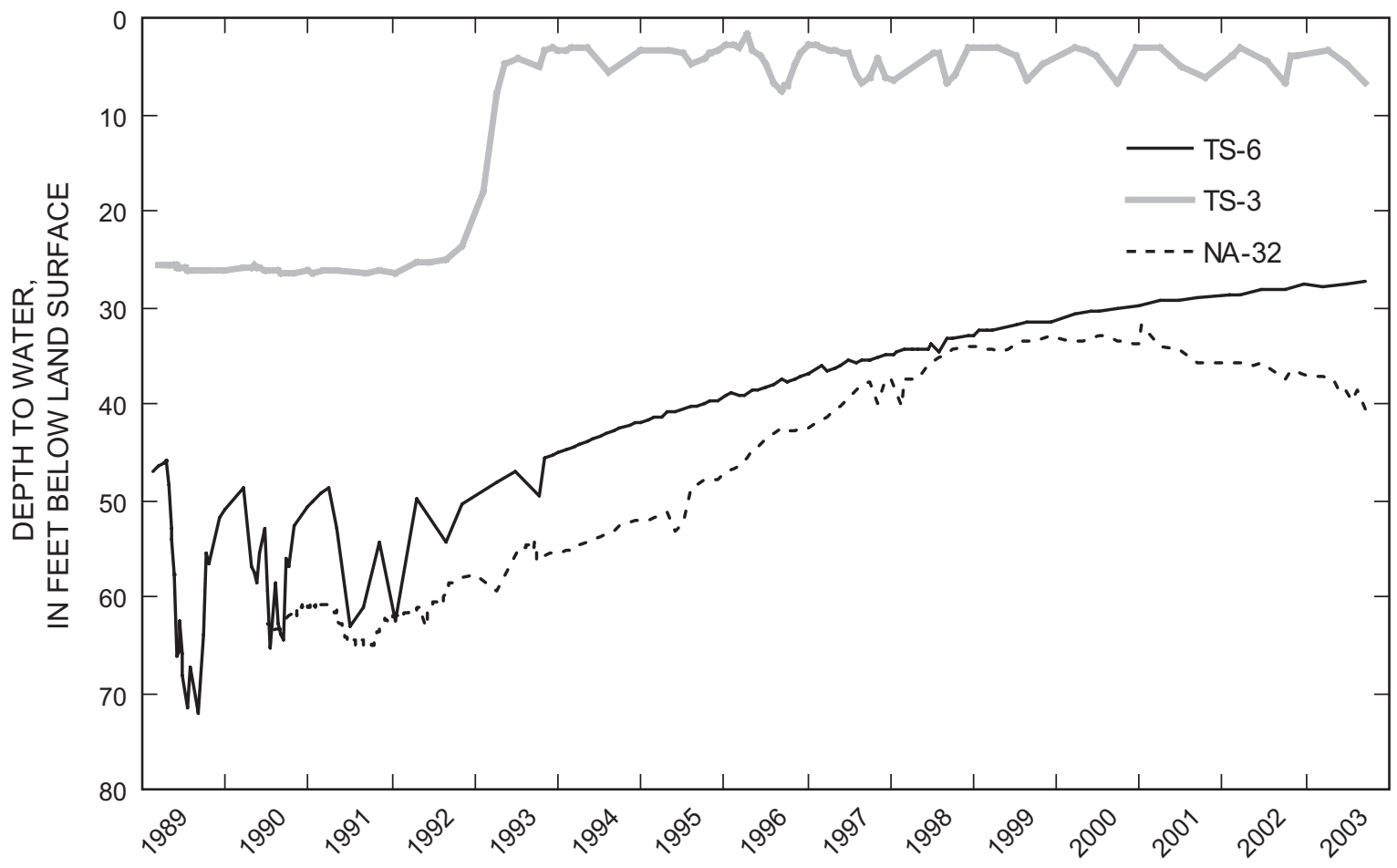

Figure 6. Depth to water in basin-fill deposits of Boulder Flat, 1989-2003. 


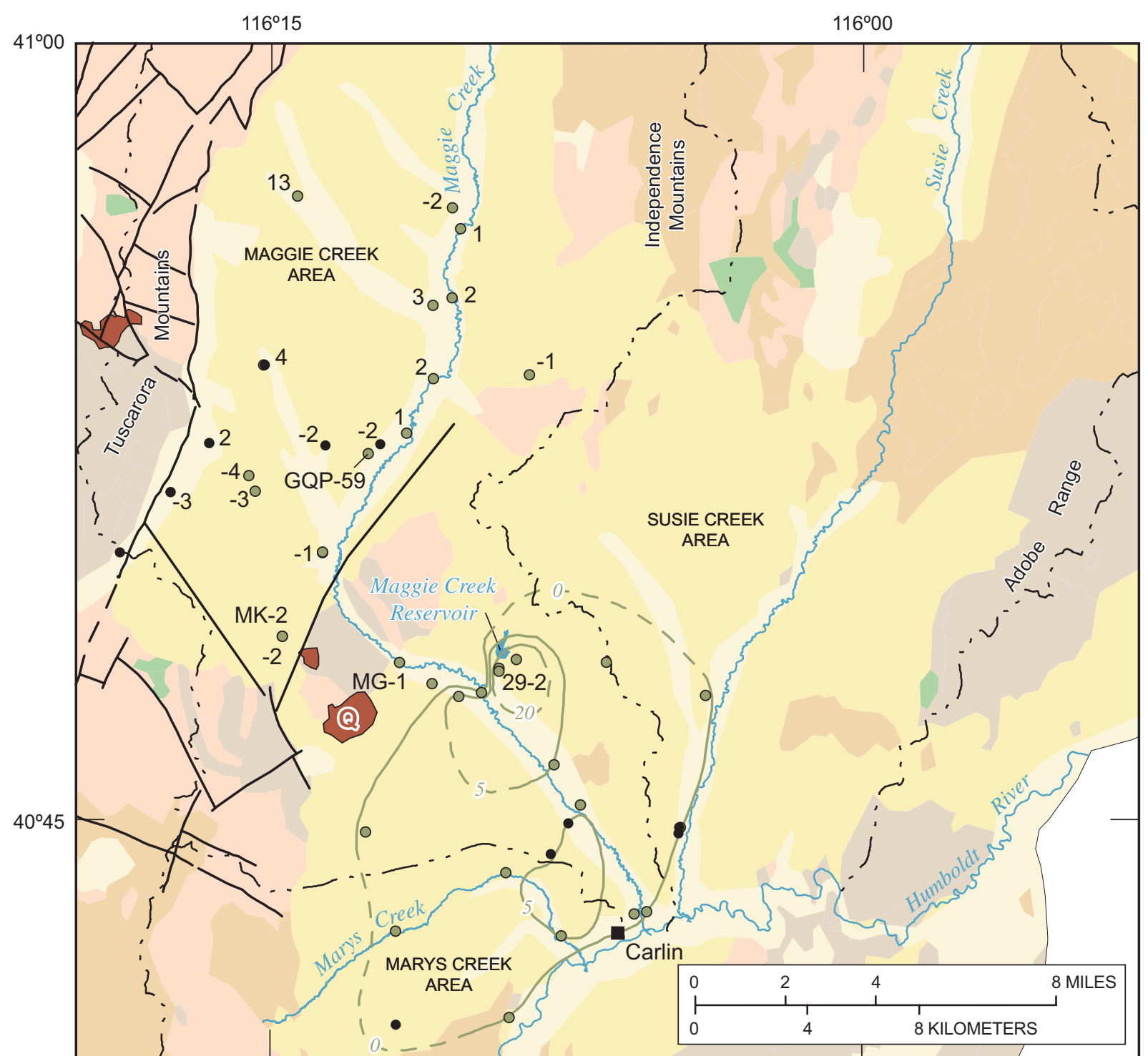

Base from U.S. Geological Survey digital data, 1:100,000, 1979-88. Universal Transverse Mercator projection, Zone 11.

Geology from Stewart and Carlson, 1976 North American Datum of 1927.

\section{EXPLANATION}

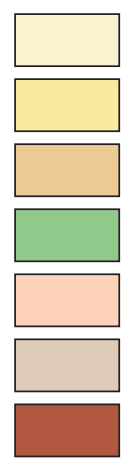

Younger basin-fill deposits

Older basin-fill deposits

Volcanic rocks

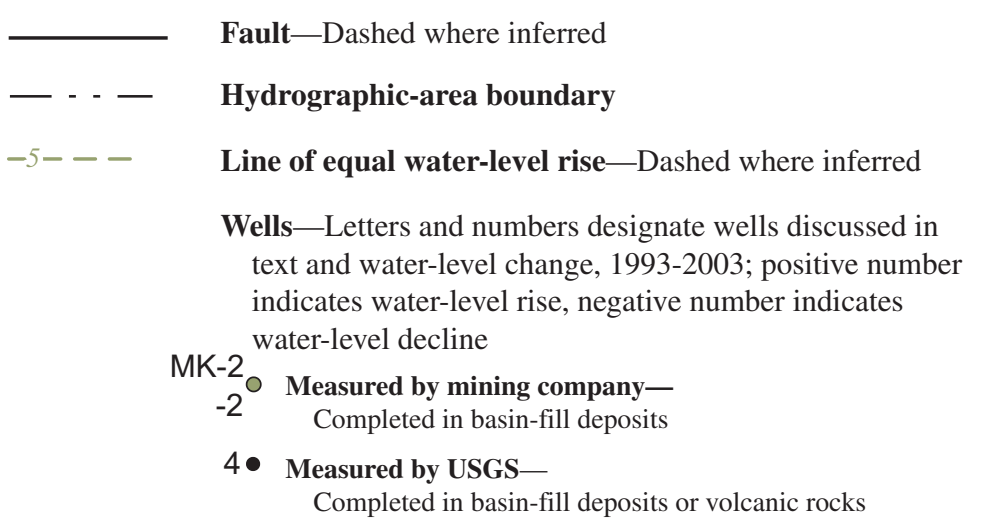

Granitic rocks

Siltstones

Carbonate rocks

Open-pit gold mine-

(Q) refers to Gold Quarry Mine

Figure 7. Water-level rises in basin-fill deposits near the Gold Quarry Mine, 1993-2003. 


\section{A}

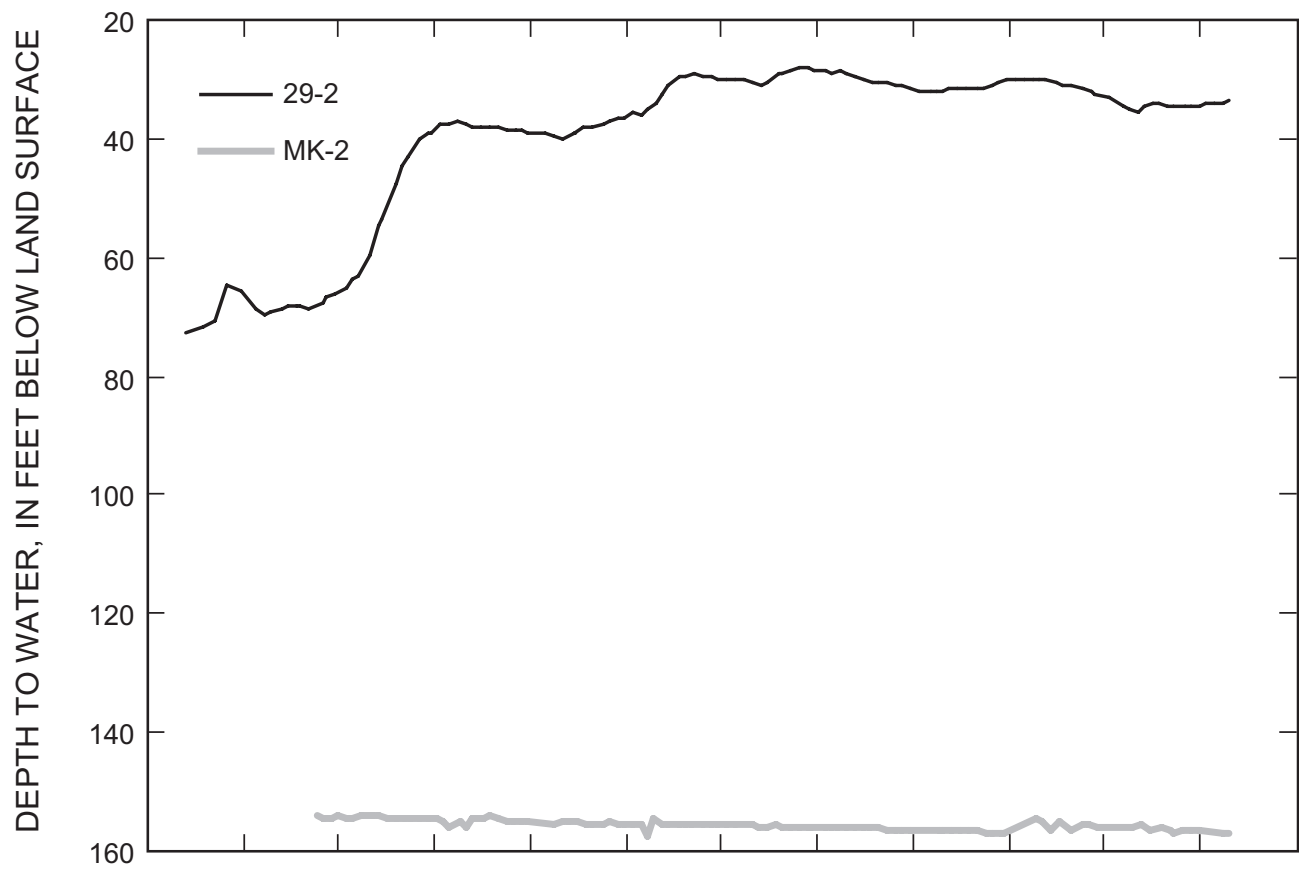

$B$

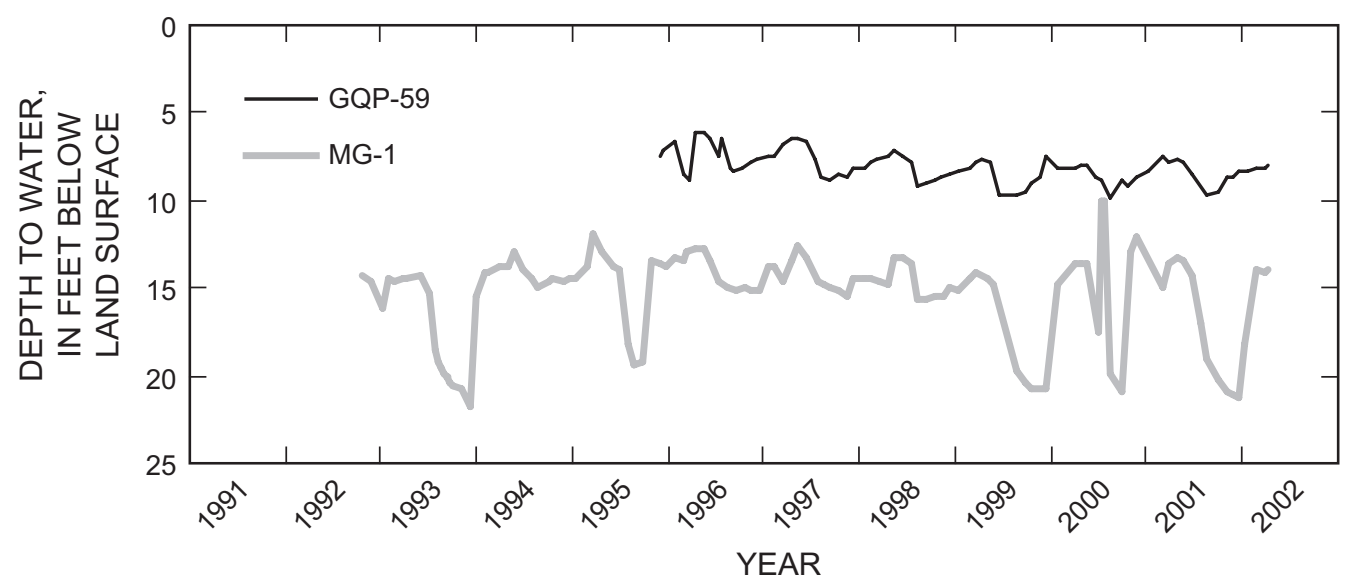

Figure 8. Depth to water in basin-fill deposits $(A)$ near Gold Quarry Mine and Maggie Creek Reservoir, 1992-2003, and (B) along Maggie Creek, 1993-2003. 
Water levels in basin-fill deposits in the Maggie Creek Area have changed in response to (1) infiltration at the Maggie Creek Reservoir, (2) infiltration at an irrigated field, (3) cessation of irrigation pumpage, (4) infiltration from releases of excess water from the Gold Quarry Mine to Maggie Creek, and (5) variations in annual runoff. From 1993 to 2003, water levels rose from $5 \mathrm{ft}$ to more than $20 \mathrm{ft}$ over an area of 6-7 $\mathrm{mi}^{2}$ around the Maggie Creek Reservoir in response to infiltration of water (fig. 7 and well 29-2, fig. 8). Farther south, water levels rose during the same period as much as $5 \mathrm{ft}$ over an area of $3 \mathrm{mi}^{2}$ for three reasons. First, excess water from the mine is used to irrigate about 100 acres, and part of this water infiltrates to the underlying aquifer as secondary recharge. Second, water from Gold Quarry Mine has replaced pumpage at two irrigation wells. Third, excess water released to Maggie Creek has increased its baseflow, part of which infiltrates permeable volcanic rocks exposed along the stream channel. The volcanic rocks are interbedded with basin-fill deposits in the subsurface and function as a permeable drain for ground-water flow to the southwest (Plume, 1995, p. 39). The line of zero water-level rise encloses an area of about $50 \mathrm{mi}^{2}$ in the lower Maggie Creek Area and adjacent parts of the Susie Creek and Marys Creek Areas (fig. 7). However, water-level rises of less than $5 \mathrm{ft}$ probably are not related to infiltration of irrigation water and streamflow, but may reflect above average precipitation from 1995 to 1998 (David E. Prudic, U.S. Geological Survey, written commun., 2004, fig. 3).

Water levels in basin-fill deposits in the Maggie Creek Area fluctuate in response to the annual runoff. Wells MG-1 and GQP-59 are used to monitor water levels in basin-fill deposits adjacent to Maggie Creek at depths of 55-65 ft and 63-68 ft, respectively (fig. 7 and 8). Well MG-1 is near a reach of Maggie Creek that has no baseflow (Plume, 1995, p. 32). Annual water-level fluctuations of 5-10 ft at this well reflect relatively dry years in 1994, 1996, and 2000-2002, whereas fluctuations of only a few feet reflect wetter years in 1997-99. Well GQP-59 is near a reach of Maggie Creek that has baseflow, and annual water-level fluctuations at this well consistently have been about $2 \mathrm{ft}$.

\section{Clovers Area}

The Clovers Area is located on the western side of the Carlin Trend area (pl. 1). The part of the Clovers Area north of the Humboldt River is sparsely developed except for an irrigated area of about 1,900 acres, 10-15 mi north of Battle Mountain (pl. 1). The first irrigation wells in this area were drilled in the early 1970's; however, water levels were not regularly measured in the area until 1989. Since then, the Nevada Division of Water Resources has measured water levels annually in March. Water-level declines have occurred over an area of 10-15 $\mathrm{mi}^{2}$ since 1990 (pl. 1). Declines have been as much as $5 \mathrm{ft}$ in the northern part of the area and as much as $15 \mathrm{ft}$ in the east-central part (pl. 1). Figure 9 shows the history of water-level change at well 20DDDD in the Clovers Area where water-level declines exceeded $15 \mathrm{ft}$.

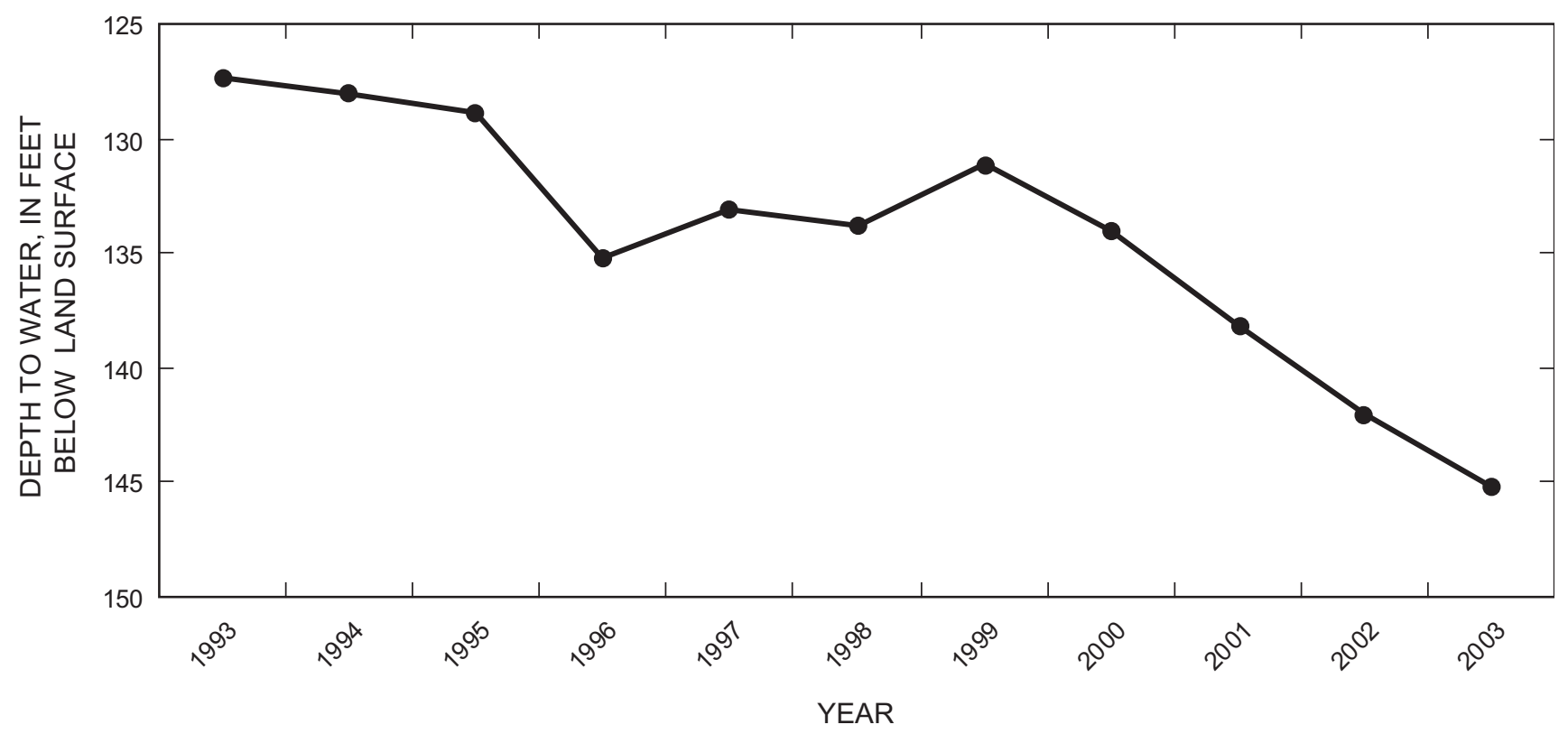

Figure 9. Depth to water at well 20DDDD in Clovers Area, 1993-2003. 


\section{Summary}

This report documents ground-water conditions and water-level changes during 1989-2003 in the Carlin Trend area of north-central Nevada. Continued gold mining activities, including mine dewatering, have resulted in large waterlevel declines and rises in different parts of the study area. The Carlin Trend area consists of the Susie, Maggie, and Marys Creek Areas, east of the Tuscarora Mountains and Boulder Flat and Rock and Willow Creek Valleys west of the mountains.

Historic ground-water pumpage in the Carlin Trend area has been for municipal, domestic, stock-watering, irrigation, and mining purposes. Pumpage for mining is by far the largest. Combined annual pumpage at the largest mines along the Carlin Trend increased from about 5,000 acre-ft in 1989 to almost 130,000 acre-ft in 1994 and 1998. Total annual pumpage has since decreased to about 45,000 acre-ft in 2003. The distribution of total pumpage during 1998 was 8 percent for consumptive use, 11 percent was returned to local aquifers by infiltration, 24 percent was used for irrigation, 52 percent was released to the Humboldt River or Maggie Creek, and 5 percent was lost to evaporation at the TS Ranch and Maggie Creek Reservoirs.

Aquifers in the Carlin Trend area occur in four hydrogeologic units. They are, from oldest to youngest: (1) carbonate rocks consisting of limestone and dolomite of Cambrian to Permian age, (2) volcanic rocks of Tertiary and Quaternary age, (3) older basin-fill deposits of Tertiary age, and (4) younger basin-fill deposits of Tertiary and Quaternary age. For purposes of evaluating water-level changes over most of the study area, the latter three units are grouped together because volcanic rocks and older basin-fill deposits commonly are interbedded and the three units are thought to be hydraulically connected. Volcanic rocks of northern Boulder Flat are an exception. Siltstones of Ordovician to Devonian age and granitic rocks of Jurassic and Tertiary age generally impede ground-water flow.

Water levels declined as much as 100-200 ft in carbonate rocks at the Gold Quarry Mine during 1990-93. Since 1992, declines have been more than $650 \mathrm{ft}$ beneath an area extending northwest from the mine. The cone of depression defines an elongate area $12 \mathrm{mi}$ long and $6 \mathrm{mi}$ wide extending southeast and northwest of Gold Quarry Mine. The shape of the depression suggests that thick, poorly permeable basin-fill deposits and the Tuscarora Mountains fault to the northwest, the GPX fault to the southwest, and an unmapped fault to the northeast may function as relatively impermeable boundaries.

By 1993, water-level declines around the Betze Mine had exceeded $800 \mathrm{ft}$. The cone of depression was bounded on the northeast and southwest by faults, on the southeast by relatively impermeable granitic rocks, and on the northwest by relatively impermeable siltstones. As of 2003, water levels had declined by more than 1,600 ft in the deepest part of the cone of depression. The area encompassed by the main part of the cone of depression, which is $7 \mathrm{mi}$ long by $4 \mathrm{mi}$ wide, did not change much during 1993-2003, although its depth had doubled. The cone of depression also extended about $5 \mathrm{mi}$ to the southeast as a result of continued dewatering of the Betze Mine. The shape of the cone of depression reflects the effects of poorly permeable granitic rocks to the southeast and the barrier effects of the Siphon fault on the southwest and the Post fault on the northeast.

Water levels in the volcanic rocks of northern Boulder Flat began to rise soon after filling of the TS Ranch Reservoir began in 1990. Since 1990, the net water level rise around the reservoir has been $50 \mathrm{ft}$ or more over $2 \mathrm{mi}^{2}$ and $20 \mathrm{ft}$ or more over an area of about $60 \mathrm{mi}^{2}$. This includes areas of exposed volcanic rocks near the reservoir and in the Sheep Creek Range and in volcanic rocks that underlie basin-fill deposits in northern Boulder Flat. Water levels at two wells rose 45-90 ft by April 1996. Water levels at the wells then declined 20-60 ft from 1996 to 1998 when pumping rates for dewatering the mine were reduced. Since 1999, water levels have fluctuated 5-20 ft each year in response to filling of the reservoir in the winter and use of water from the mine for irrigation in the spring and summer.

Water levels in basin-fill deposits in Boulder Flat have risen since 1992 for several reasons. First, water levels began to rise after pumpage for mine dewatering at the Betze Mine was substituted for irrigation pumpage. The cessation of irrigation pumping resulted in corresponding water-level rises. Second, water infiltrating volcanic rocks beneath the TS Ranch Reservoir eventually resulted in water-level rises in overlying basin-fill deposits in northern Boulder Flat. Third, application of water from the Betze Mine for irrigating about 10,000 acres in northern and eastern Boulder Flat has contributed to water-level rises. Finally, water that discharges at three new springs in northeastern Boulder Flat has resulted in saturation of basin-fill deposits downslope from the springs. As a result, water levels rose 5 to $20 \mathrm{ft}$ over an estimated area of $20 \mathrm{mi}^{2}$ in Boulder Flat. The lines of equal water-level rise have a prominent northeast inflection that is the result of local topography that directs the distribution of discharge from the three springs. The discharge from these springs in this part of Boulder Flat has resulted in saturation of basin-fill deposits to land surface.

Water-level declines during 1993-2003 in carbonate rocks near Gold Quarry do not appear to have had much affect on water levels in overlying basin-fill deposits. No declines were observed in areas south and east of the mine, and declines were no more than a few feet north and west of the mine. The reason for this is that the base of the Carlin Formation (older basin-fill deposits) consists of fine-grained lacustrine deposits that are poorly permeable; thus, there is little hydraulic connection between these units. 
Water levels in basin-fill deposits in the Maggie Creek Area have risen in response to infiltration at the Maggie Creek Reservoir, infiltration at a field irrigated with water from the Gold Quarry Mine, releases of excess water to Maggie Creek, cessation of irrigation pumpage, and variations in annual runoff. Water levels rose $5 \mathrm{ft}$ to more than $20 \mathrm{ft}$ over an area of 6-7 $\mathrm{mi}^{2}$ around the reservoir in response to infiltration. A few miles farther south, water levels rose as much as $5 \mathrm{ft}$ over an area of $3 \mathrm{mi}^{2}$ as a combined result of the infiltration of irrigation water and infiltration of Maggie Creek flow into permeable volcanic rocks in the stream channel. Water levels in basin-fill deposits in the Maggie Creek Area also fluctuate in response to the annual runoff and streamflow conditions along Maggie Creek. Annual water-level fluctuations are 5-10 ft along reaches of Maggie Creek that have no baseflow. Annual water-level fluctuations are about $2 \mathrm{ft}$ along reaches with baseflow.

An area of 1,900 acres about 10-15 mi north of Battle Mountain in the Clovers Area has been pumped for irrigation since the early 1970's; however, water levels have been regularly measured in the area only since 1989 . Water levels have declined over an area of 10-15 $\mathrm{mi}^{2}$. Declines have been $5 \mathrm{ft}$ or more in the northern part of the area and $15 \mathrm{ft}$ or more in the east-central part.

\section{References Cited}

Cardinalli, J.L., Roach, L.M., Rush, F.E., and Vasey, B.J., compilers, 1968, State of Nevada hydrographic areas: Nevada Division of Water Resources map, scale 1:500,000.

Maurer, D.K., Plume R.W., Thomas, J.M., and Johnson, A.K., 1996, Water resources and effects of changes in groundwater use along the Carlin Trend, north-central Nevada: U.S. Geological Survey Water-Resources Investigations Report 96-4134, 146 p.

Plume, R.W., 1995, Water resources and potential effects of ground-water development in Maggie, Marys, and Susie Creek Basins, Elko and Eureka Counties, Nevada: U.S. Geological Survey Water-Resources Investigations Report 94-4222, 87 p.

Plume, R.W., 2003, Ground-water use, locations of production wells, and areas irrigated using ground water in 1998, middle Humboldt River Basin, north-central Nevada: U.S. Geological Survey Water-Resources Investigations Report 03-4227, 16 p.

Plume, R.W., and Ponce, D.A., 1999, Hydrogeologic framework and ground-water levels, 1982 and 1996, middle Humboldt River Basin, north-central Nevada: U.S. Geological Survey Water-Resources Investigations Report 98-4209, 2 sheets.

Rush, F.E., 1968, Index of hydrographic areas in Nevada: Nevada Division of Water Resources, Information Report 6, $38 \mathrm{p}$.

Stewart, J.H., and Carlson, J.E., 1976, Geologic map of northcentral Nevada: Nevada Bureau of Mines and Geology, Map 50, scale 1:250,000. 
8 Printed on recycled paper 